\title{
A Practical Synthesis of 4'-Fluorospiro[cyclopropane-1,3'-indol]- 2'(1'H)-one: a Valuable Terminal Building-Block for Biologically Active Podands
}

\author{
Alexandre S. Babushkin, Maxim B. Nawrozkij, ${ }^{@}$ Ivan A. Novakov,
} and Alexandre S. Yablokov

Dedicated to Academician of Russian Academy of Sciences Oleg. G. Sinyashin on the occasion of his $60^{\text {th }}$ Anniversary

Volgograd State Technical University, 400005 Volgograd, Russian Federation

${ }^{\circledR}$ Corresponding authorE-mail: maxim.nawrozkij@vstu.ru

\begin{abstract}
A practical one-pot synthesis of 4'-fluorospiro[cyclopropane-1,3'-indol]-2'(1'H)-one, including the treatment of 1-(2,6-difluorophenyl)cyclopropane-1-carbonitrile with potassium hydroxide in boiling glycol, as a key step, is described. The title product is recognized as a promising terminal building block for the novel biologically active podands.
\end{abstract}

Keywords: Podands, one-pot synthesis, NMR spectroscopy.

\section{Усовершенствованный синтез 4'-фторспиро[циклопропан-1,3'- индол]-2'(1'H)-она: перспективного терминального билАинг- блока Аля биологически активных подандов}
A. C.
С. Бабушкин, М.
Б. Навроцкий,
И. А. Новаков, А.
А. С. Яблоков

Посвящается Акаgемику РАН О. Г. Синяшину по случаю его 60-летнего юбилея

Волгоградский государственный технический университет, 400005 Волгоград, Россия

@E-mail: maxim.nawrozkij@vstu.ru

Разработан усовершенствованный однореакторный способ синтеза 4'-фрторспиро[циклопропан-1,3'-индол]2'(1'H)-она, основанный на обработке 1-(2,6-дифторфенил)-цииллопропан-1-карбонитрила гидроксидом калия в кипящем гликоле. Целевой продукт рассматривается как перспективный терминальный билдинг-блок для получения новых биологически активных подандов.

Ключевые слова: Поданды, однореакторный синтез, ЯМР спектроскопия. 


\section{Introduction}

Podand ionophores (or podands) are considered to be a class of seco-analogues of macrocycles, yet preorganized hosts for cations. ${ }^{[1]}$ Their chemical and physical properties greatly depend on the structure of their main chain, as well as the structure of the terminal groups. It is necessary to mention that a lot of ionophores of a kind possess valuable physiological activity. For example, a number of podands are recognized as highly active antibiotics. ${ }^{[2]}$ On the other hand, a 4'-fluorospiro[cyclopropane-1,3'-indol]-2'(1'H)-one ${ }^{[3-5]}$ scaffold and its bioisosteres ${ }^{[6]}$ are important descriptors in different pharmacologically active agents, described as potential drugs for a variety of socially significant diseases. In such a case, we have made up our minds to prepare a series of podands, consisting of oligoether fragment, "locked" on both ends with the residues of 4'-fluorospiro[cyclopropane1,3'-indol] (Figure 1) and investigate their properties.

A scalable and practical synthesis of 4'-fluorospiro[cyclopropane-1,3'-indol]-2'(1'H)-one appeared crucial for the success of this work, so the present paper is dedicated to this step of the total synthesis.

\section{Experimental}

All the solvents were purified by standard methods. ${ }^{[7]}$ Melting points of the compounds were determined on Buchi M-565 apparatus (corrected values obtained at $1{ }^{\circ} \mathrm{C} / \mathrm{min}$ heating rate are presented). IR-spectra were recorded in Nujol mulls on a Spekord M-82 apparatus. Elemental analyses were performed on Vario EL Cube apparatus. GC/MS analyses were carried out using Varian Saturn $2100 \mathrm{GC} / \mathrm{MS}$-spectrometer. ${ }^{1} \mathrm{H},{ }^{13} \mathrm{C}$ and ${ }^{19} \mathrm{~F}$ NMR spectra were recorded on Bruker Avance III 400 NMR-spectrometer, equipped with a broad-band sensor with $Z$-gradient in DMSO- $d_{6}$ at $30{ }^{\circ} \mathrm{C}$ (internal standard - TMS). Chemical shifts of ${ }^{1} \mathrm{H}$ and ${ }^{13} \mathrm{C}$ were calibrated in regard to the signals of DMSO- $d_{6}$ carbon atoms $(39.50 \mathrm{ppm})$ and the residual signals of ${ }^{1} \mathrm{H}$-atoms of DMSO- $d_{6}$ $(2.50 \mathrm{ppm})$. Chemical shifts of ${ }^{19} \mathrm{~F}$ were calibrated in regard to the external standard $-\mathrm{CFCl}_{3}(0.0 \mathrm{ppm}) .{ }^{19} \mathrm{~F}$ NMR spectra were recorded with broad-band decoupling from protons, while ${ }^{1} \mathrm{H} N M R$ spectra were recorded either with broad-band decoupling from ${ }^{19} \mathrm{~F}$ nuclei, or without it. Two dimensional experiments were carried out according to the standard Bruker company methods with the help of $Z$-gradient impulses. The period of mixing in the case of NOESYspectra was $0.7 \mathrm{~s} .{ }^{1} \mathrm{H}-{ }^{13} \mathrm{C}$ HMBC-spectra were optimized for $10 \mathrm{~Hz}$ coupling constants. ${ }^{19} \mathrm{~F}-{ }^{1} \mathrm{H}$ HOESY-spectra were recorded in the proton supervision mode and mixing period was $0.5 \mathrm{~s}$.

4'-Fluorospiro[cyclopropane-1,3'-indol]-2'(1'H)-one. A mixture of 2-(2,6-difluorophenyl)acetonitrile (15.3 g, $12.4 \mathrm{ml}, 0.1 \mathrm{~mol})$, 1,2-dibromoethane (152.5 g, $70 \mathrm{ml}, 812 \mathrm{mmol})$, and benzyl(triethyl) ammonium chloride (32.7 g, $144 \mathrm{mmol})$ was vigorously stirred at $60{ }^{\circ} \mathrm{C}$ under protection from atmospheric carbon dioxide. Aqueous potassium hydroxide (prepared from $95 \mathrm{~g}$ (1.43 mol; assay $\sim 84.5 \%$ ) solid potassium hydroxide and $95 \mathrm{ml}$ of water) was added drop by drop to the reaction mixture. After the complete addition of the alkali, the reaction mixture was vigorously stirred at $60-65^{\circ} \mathrm{C}$ for $6 \mathrm{hrs}$ more and left overnight at room temperature. The whole mixture was thoroughly extracted with methyl tret-butyl ether $(3 \times 100 \mathrm{ml})$, aqueous phase was discarded, while the organic extracts were mixed together and evaporated. Traces of water were azeotropically removed with toluene, and the residue was mixed with glycol $(150 \mathrm{ml})$ and solid potassium hydroxide pellets $(22.2$ g, $0.33 \mathrm{~mol}$; assay $\sim 84.5 \%$ ). The reaction mixture was stirred at reflux under protection of atmospheric carbon dioxide, until the evolution of ammonia ceased, quenched with $300 \mathrm{ml}$ of water, treated with activated carbon, filtered and chilled in an ice box. The stirred and cooled solution was made acid to litmus by addition of concentrated $\mathrm{HCl}$ (until $\mathrm{pH} 1-2$ ) and filtered. The filtrate was thoroughly extracted with methyl tert-butyl ether $(3 \times 150 \mathrm{ml})$, while the filter cake (crude 1-(2,6-difluorophenyl)cyclopropane-1carboxylic acid) was washed with water and air-dried. Combined organic extracts were successively washed with water, brine and dried over anhydrous sodium sulphate. After filter through a silica gel pad, the organic solution was evaporated to dryness, and the viscous residue was treated several times with boiling isooctane. Upon chilling to room temperature, the combined isooctane extracts were separated several times from a small amount of tarry material, and then deposited the first crop of fine crystals of the target compound. The resulting precipitate was filtered off and airdried. The mother liquor was re-concentrated several times in vacuo to render several more crops of crystals. The overall yield of pure 4'-fluorospiro[cyclopropane-1,3'-indol]-2'(1'H)-one was $11.1 \mathrm{~g}$ (63 \%). M.p.: $74.5-75.5^{\circ} \mathrm{C}$ (from isooctane). Purity: $99.99 \%$ (GC/ MS). Found, \%: C, 69.71; H, 4.48; N, 8.00. $\mathrm{C}_{10} \mathrm{H}_{8} \mathrm{FNO}$. Calculated, \%: C, 67.79; H, 4.55; N, 7.91. Mass spectrum (EI) $m / z$ (\%): 177.9 (66) $\left[(\mathrm{M}+\mathrm{H})^{+}\right], 163.1(22)\left[\left(\mathrm{M}+\mathrm{H},-\mathrm{CH}_{2}\right)^{+}\right], 149.1(100)[(\mathrm{M}+\mathrm{H},-$ CO) $)^{+}$. IR v cm${ }^{-1}: 778 \mathrm{~m}, 1036 \mathrm{~m}, 1108 \mathrm{~s}, 1162 \mathrm{~m}, 1264 \mathrm{~m}, 1294 \mathrm{~m}$, 1492 s, 1528 m, 1636 m, 1672 s, 1816 m, 2914 s, 2956 s. ${ }^{1} \mathrm{H}$ NMR (DMSO- $\left.d_{6}, 303 \mathrm{~K}\right) \delta_{\mathrm{H}}$ ppm: $12.2(1 \mathrm{H}$, br. s, NH), $7.32(1 \mathrm{H}, \mathrm{dt}$, $\left.J_{1}=5.2 \mathrm{~Hz}, J_{2}=8.3 \mathrm{~Hz}, \mathrm{C}^{6} \mathrm{H}\right), 7.12\left(1 \mathrm{H}, \mathrm{d}, J=8.2 \mathrm{~Hz}, \mathrm{C}^{7} \mathrm{H}\right), 6.97$ $\left(1 \mathrm{H}, \mathrm{t}, J=9.2 \mathrm{~Hz}, \mathrm{C}^{5} \mathrm{H}\right), 1.95\left(2 \mathrm{H}, \mathrm{m}, \mathrm{C}^{2} \mathrm{H}(\right.$ endo $), \mathrm{C}^{3} \mathrm{H}$ (endo $\left.)\right), 1.73$ (2H, m, $\mathrm{C}^{2} \mathrm{H}($ exo $), \mathrm{C}^{3} \mathrm{H}($ exo $\left.)\right)$.

The tarry material deposited from isooctane solutions was mixed together with an air-dried crude 1-(2,6-difluorophenyl) cyclopropane-1-carboxylic acid and re-crystallized from boiling toluene. A batch of pure 1-(2,6-difluorophenyl)cyclopropane1-carboxylic acid was obtained in this manner. Yield: $4.0 \mathrm{~g}$ (20 \%). M.p.: $156-157{ }^{\circ} \mathrm{C}$ (from toluene). Purity: $99.99 \%$ (GC/ MS). Found, \%: $\mathrm{C}, 60.50 ; \mathrm{H}, 4.08 . \mathrm{C}_{10} \mathrm{H}_{8} \mathrm{~F}_{2} \mathrm{O}_{2}$. Calculated, \%: $\mathrm{C}$, 60.61; H, 4.07. Mass spectrum (EI) $m / z(\%): 197.9(100)\left[\mathrm{M}^{+}\right]$, 153.0 (37) $\left[(\mathrm{M}-\mathrm{C}(\mathrm{O}) \mathrm{OH})^{+}\right], 133.0$ (35) $\left[(\mathrm{M}-\mathrm{C}(\mathrm{O}) \mathrm{OH},-\mathrm{HF})^{+}\right]$, $127.2\left[\left(2,6-\mathrm{F}_{2} \mathrm{C}_{6} \mathrm{H}_{3} \mathrm{CH}_{2}\right)^{+}\right](32) . \mathrm{IR} v \mathrm{~cm}^{-1}: 412 \mathrm{~s}, 772 \mathrm{~m}, 946 \mathrm{~m}$, $994 \mathrm{~m}, 1048 \mathrm{~s}, 1246 \mathrm{~m}, 1270 \mathrm{~m}, 1306 \mathrm{~m}, 1324 \mathrm{~m}, 1414 \mathrm{~m}, 1468 \mathrm{~m}$, $1474 \mathrm{~m}, 1504 \mathrm{~s}, 1624 \mathrm{~m}, 1666 \mathrm{~m}, 1726 \mathrm{~s} .{ }^{1} \mathrm{H}$ NMR (DMSO-d, $303 \mathrm{~K}) \delta_{\mathrm{H}}$ ppm: $12.54\left(1 \mathrm{H}\right.$, br. s, OH), $7.36\left(1 \mathrm{H}, \mathrm{m}, \mathrm{C}^{4} \mathrm{H}\right), 7.03(2 \mathrm{H}$, $\left.\mathrm{m}, \mathrm{C}^{3,5} \mathrm{H}\right), 1.58\left(2 \mathrm{H}, \mathrm{m}, \mathrm{C}^{2} \mathrm{H}(\right.$ endo $), \mathrm{C}^{3} \mathrm{H}($ endo $\left.)\right), 1.18\left(2 \mathrm{H}, \mathrm{m}, \mathrm{C}^{2} \mathrm{H}\right.$ (exo), $\mathrm{C}^{3} \mathrm{H}($ exo $)$ ).

\section{Results and Discussion}

4'-Fluorospiro[cyclopropane-1,3'-indol]-2'(1'H)-one is a known compound, but the methods for its preparation described in literature are tedious and/or unreliable.

For example, Wilk B.K. ${ }^{[3]}$ has reported the synthesis of this compound upon treatment of 1-(2,6-difluorophenyl)cyclopropane-1-carboxamide with lithium hydride in absolute DMF at 120 for $4 \mathrm{hrs}$. Noteworthy that the melting point of the target compound was $171.1-172.2^{\circ} \mathrm{C}$ (from ethyl acetate). Alternatively, sodium tert-pentoxide in NMP was used as a base for intramolecular $N$-arylation of technical 1-(2,6-difluorophenyl)cyclopropane-1-carboxamide, conducted at $143-147{ }^{\circ} \mathrm{C}$ for $4-9$ hrs. ${ }^{[4]}$ Finally, Gontcharov A.V. and Potoski J.R. have reported the synthesis of 4'-fluorospiro[cyclopropane-1,3'-indol]-2'(1'H)-one via 3,3-dialkylation of 4-fluoroindoline-2-one with 1,2-dibromoetane in absolute THF in the presence of LDA, generated in situ from DIPA and $n$-butyllithium, at $-40 \div-20{ }^{\circ} \mathrm{C} .{ }^{[5]}$ The main drawback of the above mentioned procedures is a com- 


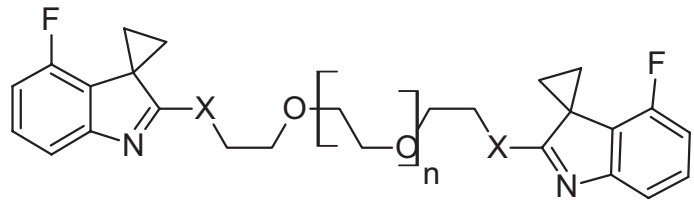

Figure 1. General structure of 4'-fluorospiro[cyclopropane-1,3'indol]-based podand ionophores (where $\mathrm{X}$ is $\mathrm{O}, \mathrm{S}$ or substituted $\mathrm{N}$ atom and $n \geq 1$ ).

bination of highly flammable base with very high or, oppositely, extremely low temperatures of the reaction. On the other hand, preparation of the intermediate 1-(2,6-difluorophenyl)cyclopropane-1-carbonitrile via the $\alpha, \alpha$-dialkylation of 2-(2,6-difluorophenyl)acetonitrile with 1,2-dibromoethane in the presence of sodium hydroxide and a catalytic amount of tetrabutylammonium bromide ${ }^{[3,8]}$ has given inconsistent yields of the title nitrile.

To overcome these difficulties, we have totally revisited the whole procedure for the synthesis of 4'-fluorospiro[cyclopropane-1,3'-indol]-2'(1'H)-one (Figure 2) starting from the very beginning. 2-(2,6-Difluoro- phenyl)acetonitrile was synthesized from 2-(chloromethyl)1,3-difluorobenzene ${ }^{[9]}$ by the known procedure. ${ }^{[10]}$ The latter compound was treated with an excess of 1,2-dibromoethane in the presence of concentrated aqueous potassium hydroxide $^{[11]}$ and an equimolecular amount of Makosza catalyst. ${ }^{[12]}$ These conditions have allowed the complete conversion of the starting nitrile. The reaction mixture was ethered out to yield the desired 1-(2,6-difluorophenyl)cyclopropane-1-carbonitrile, slightly contaminated with 1-(2,6-difluorophenyl) cyclopropane-1-carboxamide. The whole reaction product was treated with an excess of potassium hydroxide in boiling glycol (while partial hydrolysis of the starting nitrile and cyclization of the intermediate amide took place). After quenching the reaction mixture with water and subsequent acidification, the aqueous solution was filtered from a small amount of 1-(2,6-difluorophenyl)cyclopropane-1-carboxylic acid (appears due to the complete saponification), and the target 4'-fluorospiro[cyclopropane-1,3'-indol]-2'(1'H)-one was isolated via extractive work-up of the filtrate.

It is necessary to point out that 4'-fluorospiro[cyclopropane-1,3'-indol]-2'(1'H)-one prepared in this manner was crystallized from isooctane (not ethyl acetate) and had a melting point $74.5-76.5^{\circ} \mathrm{C}$, that is not in agreement with the literature values. ${ }^{[3]}$ The same was observed in the case

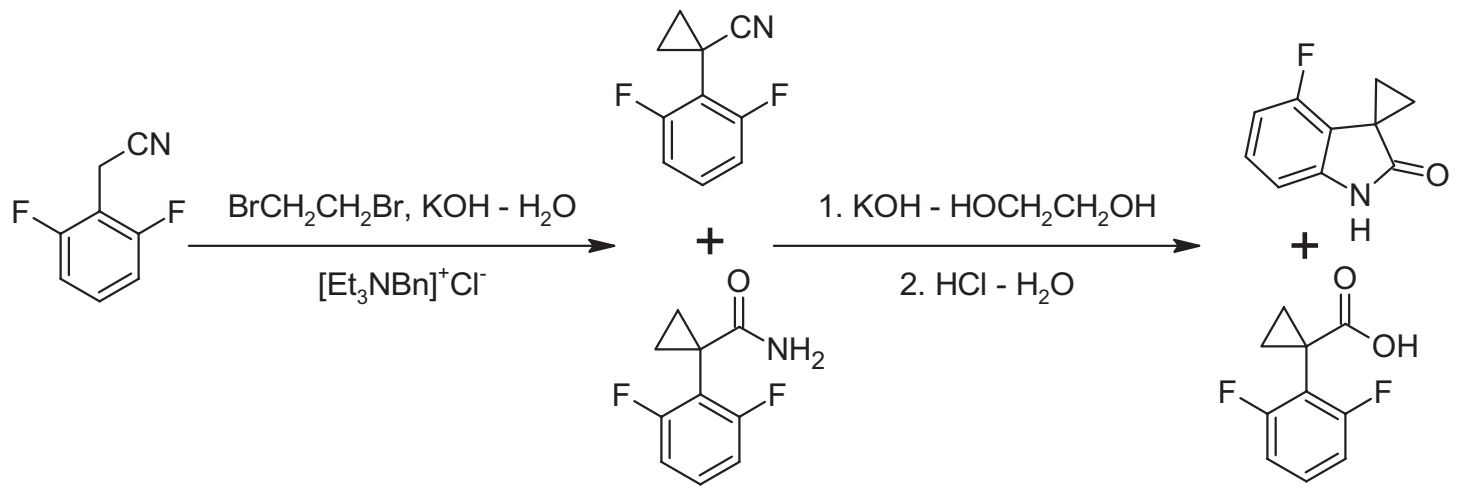

Figure 2. Synthesis of 4'-fluorospiro[cyclopropane-1,3'-indol]-2'(1'H)-one from 2-(2,6-difluorophenyl)acetonitrile.

Table 1. NMR spectral data for 4'-fluorospiro[cyclopropane-1,3'-indol]-2'(1'H)-one.

\begin{tabular}{|c|c|c|c|c|}
\hline Position & ${ }^{1} \mathrm{H}\left({ }^{19} \mathrm{~F}\right)$ & ${ }^{13} \mathrm{C}$ & NOE & HMBC \\
\hline $\mathrm{N}-1$ (indole) & $1 \mathrm{H}, 12.2$ br. s, $\mathrm{NH}$ & - & - & - \\
\hline C-2 (indole) & - & $1 \mathrm{C}, 175.71 \mathrm{~s}$ & - & - \\
\hline C-3 (indole) & - & $1 \mathrm{C}, 23.66, \mathrm{~d},{ }^{3} J_{\mathrm{CF}}=1.8 \mathrm{~Hz}$ & - & - \\
\hline C-3a (indole) & - & $1 \mathrm{C}, 114.96 \mathrm{~d},{ }^{2} J_{\mathrm{CF}}=19.0 \mathrm{~Hz}$ & - & - \\
\hline C-4 (indole) & $(1 \mathrm{~F},-125.76 \mathrm{~s})$ & $1 \mathrm{C}, 155.77, \mathrm{~d},{ }^{1} J_{\mathrm{CF}}=245.9 \mathrm{~Hz}$ & $\begin{array}{l}\mathrm{H}-5 \text { (indole), } \mathrm{H}-2,3 \\
\text { (endo, cyclopropane) }\end{array}$ & - \\
\hline C-5 (indole) & $1 \mathrm{H}, 6.97 \mathrm{t},{ }^{3} J_{\mathrm{H}-5, \mathrm{~F}-4}={ }^{3} J_{\mathrm{H}-5 \mathrm{H}-6}=9.2 \mathrm{~Hz}$ & $1 \mathrm{C}, 111.02, \mathrm{~d},{ }^{2} J_{\mathrm{CF}}=19.2 \mathrm{~Hz}$ & - & C-3a, $4,6,7$ (indole) \\
\hline C-6 (indole) & $\begin{array}{c}1 \mathrm{H}, 7.32 \mathrm{dt},{ }^{4} J_{\mathrm{H}-6, \mathrm{~F}-4}=5.9 \mathrm{~Hz} \\
{ }^{3} J_{\mathrm{H}-5, \mathrm{~F}-6}={ }^{3} J_{\mathrm{H}-6, \mathrm{H}-7}=8.3 \mathrm{~Hz}\end{array}$ & $1 \mathrm{C}, 128.70, \mathrm{~d},{ }^{3} J_{\mathrm{CF}}=8.4 \mathrm{~Hz}$ & - & C-4,5,7a (indole) \\
\hline C-7 (indole) & $1 \mathrm{H}, 7.12 \mathrm{~d},{ }^{3} J_{\mathrm{H}-6, \mathrm{H}-7}=8.2 \mathrm{~Hz}$ & $1 \mathrm{C}, 106.98, \mathrm{~d},{ }^{4} J_{\mathrm{CF}}=3.8 \mathrm{~Hz}$ & - & C-3a, $5,7 \mathrm{a}$ (indole) \\
\hline C-7a (indole) & - & $1 \mathrm{C}, 153.87, \mathrm{~d},{ }^{3} J_{\mathrm{CF}}=9.0 \mathrm{~Hz}$ & - & - \\
\hline $\begin{array}{c}\mathrm{C}-2,3 \\
\text { (cyclopropane) }\end{array}$ & $\begin{array}{l}2 \mathrm{H}(\text { endo }), 1.95 \mathrm{~m} \\
2 \mathrm{H}(\text { exo }), 1.73 \mathrm{~m}\end{array}$ & $2 \mathrm{C}, 18.57, \mathrm{~d},{ }^{4} J_{\mathrm{CF}}=1.2 \mathrm{~Hz}$ & F-4 (indole) & $\begin{array}{l}\text { C-2,3,3a (indole) } \\
\text { C-2,3,3a (indole) }\end{array}$ \\
\hline
\end{tabular}


Table 2. NMR spectral data for 1-(2,6-difluorophenyl)cyclopropane-1-carboxylic acid.

\begin{tabular}{|c|c|c|c|c|}
\hline Position & ${ }^{1} \mathrm{H}\left({ }^{19} \mathrm{~F}\right)$ & ${ }^{13} \mathrm{C}$ & $\mathrm{NOE}$ & HMBC \\
\hline C (carboxyl) & $1 \mathrm{H}, 12.54$, br. s, OH & $1 \mathrm{C}, 173.78$ & $\begin{array}{c}\mathrm{H}-2,3 \text { (exo, } \\
\text { cyclopropane) }\end{array}$ & - \\
\hline C-1 (cyclopropane) & - & $1 \mathrm{C}, 17.63, \mathrm{t}, J_{\mathrm{CF}}=2.2 \mathrm{~Hz}$ & - & - \\
\hline C-2,3 (cyclopropane) & $\begin{array}{l}2 \mathrm{H}(\text { endo }), 1.58, \mathrm{~m} \\
2 \mathrm{H}(\text { exo }), 1.18, \mathrm{~m}\end{array}$ & $2 \mathrm{C}, 17.63, \mathrm{t}, J_{\mathrm{CF}}=2.3 \mathrm{~Hz}$ & $\begin{array}{l}\mathrm{F}-5 \\
1-\mathrm{OH}\end{array}$ & $\begin{array}{c}\text { C (carboxyl), C-2,3 } \\
\text { (cyclopropane), C-1 (benzene) } \\
\text { C (carboxyl), C-2,3 } \\
\text { (cyclopropane), C-1 (benzene) }\end{array}$ \\
\hline C-1 (benzene) & - & $1 \mathrm{C}, 115.99, \mathrm{t}, J_{\mathrm{CF}}=17.3 \mathrm{~Hz}$ & - & - \\
\hline C-2,6 (benzene) & $(1 \mathrm{~F},-112.28, \mathrm{~s})$ & $\begin{array}{c}2 \mathrm{C}, 162.01, \mathrm{dd}, \\
J_{\mathrm{CF}}=247.7 \mathrm{~Hz} ; 7.6 \mathrm{~Hz}\end{array}$ & $\begin{array}{c}\mathrm{H}-2,3 \text { (endo, } \\
\text { cyclopropane), } \\
\mathrm{H}-3,5 \text { (benzene) }\end{array}$ & - \\
\hline C-3,5 (benzene) & $2 \mathrm{H}, 7.03, \mathrm{~m}$ & $\begin{array}{c}2 \mathrm{C}, 111.36, \mathrm{dd}, \\
J_{\mathrm{CF}}=6.3 \mathrm{~Hz} ; 12.3 \mathrm{~Hz}\end{array}$ & - & C-1,2,3,5,6 (benzene) \\
\hline C-4 (benzene) & $1 \mathrm{H}, 7.36, \mathrm{~m}$ & $1 \mathrm{C}, 129.64, \mathrm{t}, J_{\mathrm{CF}}=10.5 \mathrm{~Hz}$ & - & C-1,2,3,5,6 (benzene) \\
\hline
\end{tabular}

of 1-(2,6-difluorophenyl)cyclopropane-1-carboxylic acid (melting point $-156-157^{\circ} \mathrm{C}$ (from toluene) vs. the literature data $\left.^{[11]} 150-153^{\circ} \mathrm{C}\right)$. That is why, we had to use a correlation NMR-spectroscopy methods (Table 1 and Table 2), together with GC-MS and elemental analyses of these products to establish and approve their chemical structure.

\section{Conclusions}

A scalable and simple one-pot procedure for the synthesis of 4'-fluorospiro[cyclopropane-1,3'-indol]-2'(1'H)one, starting from 2-(2,6-difluorophenyl)acetonitrile, was developed. The main achievement of this method is that the title compound is prepared and separated in an easy way, and the whole synthesis requires only one cheap base - potassium hydroxide instead of the expensive and flammable bases reported previously. ${ }^{[3-5]}$ Meanwhile, the method also allows the production of 1-(2,6-difluorophenyl)cyclopropane-1-carboxylic acid useful in the synthesis of different pesticides. ${ }^{[8,11]}$

Acknowledgements. This work was supported by RFBR Grant No. 16-33-60003 mol_a_dk.

\section{References}

1. Iimori T., Still W.C., Rheingold A.L., Staley D.L. J. Am. Chem. Soc. 1989, 111, 3439-3440.

2. Martí-Centelles V., Pandey M.D., Burguete M.I., Luis S.V. Chem. Rev. 2015, 115, 8736-8834.

3. Patent US 2006/0247441 A1, 2006.

4. Patent US 2008/0319204 A1, 2008.

5. Patent US 2008/0051585 A1, 2008.

6. Alimardanov A., Gontcharov A., Nikitenko A., Chan A. W., Ding Z., Ghosh M., Levent M., Raveendranath P., Ren J., Zhou M., Mahaney P.E., McComas C.C., Ashcroft J., Potoski J.R. Org. Proc. Res. Dev. 2009, 13, 880-887.

7. Tietze L.F., Eicher T. Reaktionen und Synthesen im Organischchemischen Praktikum und Forschungslaboratorium, 2. Auflage, Weinheim: Wiley-VCH Verlag $\mathrm{GmbH} \& \mathrm{Co}, 1991$. $703 \mathrm{p}$.

8. Patent US 4859232, 1989.

9. Malykhin E.V., Shteingarts V.D. J. Fluor. Chem. 1998, 91, 19-20.

10. Jerumanis S., Bruylants A. Bull. Soc. Chim. Belg. 1960, 69, 312-322.

11. Patent US 5371268, 1994.

12. Sychkova L.D., Shabarov Yu.S. Zh. Org. Khim. 1980, 16, 2086-2091(in Russ.). 